\title{
Farnesoid X Receptor Agonists Obeticholic Acid and Chenodeoxycholic Acid Increase Bile Acid Efflux in Sandwich- Cultured Human Hepatocytes: Functional Evidence and Mechanisms
}

\author{
Cen Guo, Carl LaCerte, Jeffrey E. Edwards, Kenneth R. Brouwer, and Kim L. R. Brouwer
}

Division of Pharmacotherapy and Experimental Therapeutics, UNC Eshelman School of Pharmacy, University of North Carolina at Chapel Hill, Chapel Hill, North Carolina (C.G., K.L.R.B.); Intercept Pharmaceuticals, San Diego, California (C.L., J.E.E.); and Qualyst Transporter Solutions, Durham, North Carolina (K.R.B.)

Received December 8, 2017; accepted February 20, 2018

\section{ABSTRACT}

The farnesoid $X$ receptor $(F X R)$ is a nuclear receptor that regulates genes involved in bile acid homeostasis. FXR agonists, obeticholic acid (OCA) and chenodeoxycholic acid (CDCA), increase mRNA expression of efflux transporters in sandwich-cultured human hepatocytes $(\mathrm{SCHH})$. This study evaluated the effects of OCA and CDCA treatment on the uptake, basolateral efflux, and biliary excretion of a model bile acid, taurocholate (TCA), in SCHH. In addition, changes in the protein expression of TCA uptake and efflux transporters were investigated. SCHH were treated with $1 \mu \mathrm{M} \mathrm{OCA}$, $100 \mu \mathrm{M}$ CDCA, or vehicle control for 72 hours followed by quantification of deuterated TCA uptake and efflux over time in $\mathrm{Ca}^{2+}$-containing and $\mathrm{Ca}^{2+}$-free conditions ( $n=3$ donors). A mechanistic pharmacokinetic model was fit to the TCA mass-time data to obtain estimates for total uptake clearance (CL Uptake), total intrinsic basolateral efflux clearance $\left(\mathrm{CL}_{\text {int,BL }}\right)$, and total intrinsic biliary clearance $\left(\mathrm{CL}_{\text {int,Bile }}\right)$. Modeling results revealed that FXR agonists significantly increased $\mathrm{CL}_{\text {int,BL }}$ by $>6$-fold and significantly increased $\mathrm{CL}_{\text {int,Bile }}$ by 2-fold, with minimal effect on $\mathrm{CL}_{\text {Uptake. }}$ Immunoblotting showed that protein levels of the basolateral transporter subunits organic solute transporter $\alpha$ and $\beta$ (OST $\alpha$ and OST $\beta$ ) in FXR agonist-treated SCHH were significantly induced by $>2.5-$ and 10-fold, respectively. FXR agonist-mediated changes in the expression of other TCA transporters in $\mathrm{SCHH}$ were modest. In conclusion, this is the first report demonstrating that OCA and CDCA increased TCA efflux in $\mathrm{SCHH}$, which contributed to reduced intracellular TCA concentrations. Increased basolateral efflux of TCA was consistent with increased OST $\alpha / \beta$ protein expression in OCA- and CDCA-treated SCHH.

\section{Introduction}

The farnesoid $\mathrm{X}$ receptor $(\mathrm{FXR})$ is a nuclear receptor that regulates genes involved in the homeostasis of bile acids (Lefebvre et al., 2009). Bile acids are signaling molecules that

This work was supported by Intercept Pharmaceuticals and the National Institutes of Health National Institute of General Medical Sciences [Grants R01-GM041935 and R35-GM122576]. C.G. is supported, in part, by the University of North Carolina Royster Society of Fellows. K.L.R.B. is a coinventor of the sandwich-cultured hepatocyte technology for quantification of biliary excretion (B-CLEAR) and related technologies, which have been licensed exclusively to Qualyst Transporter Solutions LLC. B-CLEAR is covered by U.S. patent $6,780,580$ and other U.S. and international patents both issued and pending.

This work was presented, in part, as a poster at the following conferences: Guo C, LaCerte C, Edwards J, Brouwer KR, Brouwer KLR. Mechanistic pharmacokinetic modeling revealed functional increase in bile acid efflux by the FXR agonists obeticholic acid and chenodeoxycholic acid. Eighth American Conference on Pharmacometrics (Fort Lauderdale, FL, Oct. 16-18, 2017); Guo C, Brouwer KLR. Impact of hepatic efflux transporter modulation on bile acid disposition: prediction and evaluation using mechanistic pharmacokinetic modeling. American Association of Pharmaceutical Scientists Annual Meeting (San Diego, CA, Nov. 13-15, 2017); and Guo C, Edwards J, LaCerte C, Freeman KM, Brouwer KR, Brouwer KLR. Functional increase in bile acid efflux after treatment of sandwich-cultured human hepatocytes with the FXR agonists chenodeoxycholic acid and obeticholic acid. Third Workshop of the International Transporter Consortium in 2017 (Washington D.C., Mar. 13-14, 2017).

https://doi.org/10.1124/jpet.117.246033. modulate hepatic metabolic and transporter function (Dawson et al., 2009), inflammation (Allen et al., 2011), and lipid, glucose, and energy homeostasis (Staels and Kuipers, 2007; Thomas et al., 2008; Lefebvre et al., 2009). Therefore, FXR is a promising novel drug target to treat metabolic and chronic liver diseases such as nonalcoholic steatohepatitis and primary sclerosing cholangitis (Fiorucci et al., 2007; Jiang et al., 2007; Wagner et al., 2011; Trivedi et al., 2016). The first-inclass FXR agonist, obeticholic acid (OCA), has been approved for the treatment of primary biliary cholangitis. FXR is activated by various bile acids; chenodeoxycholic acid (CDCA) and conjugated CDCA species are the most potent natural agonists. OCA is an analog of CDCA, with 100-fold higher FXR activation potency (the median effective concentration is $99 \mathrm{nM}$ for OCA vs. $8.3 \mu \mathrm{M}$ for CDCA) (Soisson et al., 2008; Markham and Keam, 2016).

Activation of FXR protects against the toxic accumulation of bile acids by decreasing bile acid synthesis and regulating bile acid transport (Adorini et al., 2012). For example, FXR activation by CDCA increased mRNA expression of bile acid efflux transporters including the bile salt export pump (BSEP)

ABBREVIATIONS: BEI, biliary excretion index; BRI, buffer recovery index; BSA, bovine serum albumin; BSEP, bile salt export pump; CDCA,

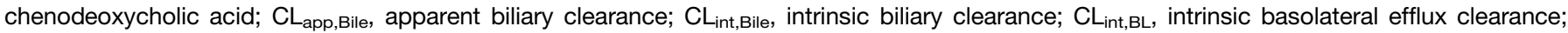

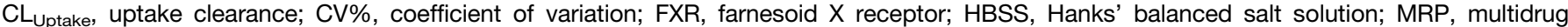
resistance-associated protein; NTCP, sodium taurocholate cotransporting polypeptide; OCA, obeticholic acid; OST, organic solute transporter; PK, pharmacokinetic; $\mathrm{SCHH}$, sandwich-cultured human hepatocytes; TCA, taurocholic acid. 
(Yu et al., 2002; Modica et al., 2010), multidrug resistanceassociated protein 2 (MRP2) (Modica et al., 2010; Liu et al., 2014 ), and organic solute transporter $(\mathrm{OST} \alpha / \beta)$ (Boyer et al., 2006; Modica et al., 2010; Liu et al., 2014) in hepatic cell lines and primary human hepatocytes. Sandwich-cultured human hepatocytes $(\mathrm{SCHH})$ are a physiologically relevant model that maintains transporter function, morphology, and regulatory machinery (LeCluyse et al., 2000; Yang et al., 2016) and therefore, is an ideal system to study the regulation of bile acid transporters after nonacute ( $>24$-hour) treatment of hepatocytes with FXR agonists. Recent studies revealed that OCA and CDCA treatment of SCHH for 72 hours increased mRNA expression of OST $\alpha / \beta$ and BSEP with minor changes in MRP3, MRP4, and sodium taurocholate cotransporting polypeptide (NTCP) (Jackson et al., 2016; Zhang et al., 2017).

Unlike drug-metabolizing enzymes, changes in gene expression of transporters do not always translate to changes in protein expression (Ahlin et al., 2009; Thompson et al., 2017) and/or function (Ohtsuki et al., 2012). This discrepancy may be explained by the prominent role of posttranscriptional regulation of hepatic transporters and the importance of transporter localization in determining transporter function (Wang et al., 2002; Chandra et al., 2005; Zhang et al., 2005; Gu and Manautou, 2010; Schonhoff et al., 2013).

Due to discrepancies between gene expression and transporter function, direct functional evidence for FXR agonistmediated induction of bile acid efflux transporters (i.e., $\mathrm{OST} \alpha / \beta$ and BSEP) is lacking. One of the challenges in quantitative assessment of hepatic transporter function is the multiplicity of transporters expressed on the basolateral and canalicular membranes of hepatocytes and the concurrent uptake and efflux of bile acids. Studies showed reduced intracellular accumulation of deuterium-labeled taurocholic acid $\left(d_{8}-\mathrm{TCA}\right)$, a prototypical bile acid, after treatment of SCHH with OCA and CDCA (Jackson et al., 2016; Zhang et al., 2017). Since $d_{8}$-TCA was added exogenously and the synthesis rate of TCA does not play a role, this change could be due to increased efflux or decreased uptake of $d_{8}$-TCA. On the basolateral membrane of human hepatocytes, NTCP and, to a much lesser extent, the organic anion-transporting polypeptides contribute to TCA uptake. MRP3, MRP4, and OST $\alpha / \beta$ are responsible for the basolateral efflux of TCA from human hepatocytes to the sinusoidal blood. (Seward et al., 2003; Zhang et al., 2003; Rius et al., 2006; Ballatori et al., 2008; Soroka et al., 2010). To deconvolute these processes, a more sophisticated method such as pharmacokinetic (PK) modeling is needed. To assess the function of the canalicular transporter BSEP, TCA biliary excretion can be quantified in SCHH using B-CLEAR technology (Qualyst Transporter Solutions, Durham, NC).

In this study, mechanistic PK modeling of data obtained from SCHH using B-CLEAR technology and our previously published basolateral efflux protocol (Pfeifer et al., 2013; Yang et al., 2015; Guo et al., 2016) was used to characterize the functional changes in bile acid transporters that occur with FXR activation. Changes in the basolateral uptake clearance, intrinsic basolateral efflux clearance, and intrinsic biliary clearance of an exogenously administered model bile acid, $d_{8}$-TCA, were evaluated in SCHH after 72-hour treatment with OCA and CDCA to reflect the transporter function. To identify the transporters that might be responsible for alterations in the overall clearance, the protein expression of TCA uptake and efflux transporters was assessed by immunoblot analysis.

\section{Materials and Methods}

Materials. BioCoat cell culture plates and Matrigel were obtained from BD Biosciences (San Jose, CA). QualGro medium was obtained from Qualyst Transporter Solutions. $d_{8}$-TCA was obtained from Toronto Research Chemicals (Toronto, ON, Canada). The Pierce bicinchoninic acid protein assay was obtained from Thermo Fisher Scientific (Waltham, MA).

Primary antibodies for OST $\alpha$, OST $\beta$, BSEP, and NTCP were purchased from Abcam (Cambridge, MA). Primary antibodies for MRP3 and MRP4 were obtained from Cell Signaling Technology (Danvers, MA) and Everest Biotech (Ramona, CA), respectively. The primary antibody for ATPase and all of the secondary antibodies were purchased from Santa Cruz Biotechnology (Dallas, TX). Other reagents for immunoblot were obtained from Bio-Rad (Hercules, CA) or Thermo Fisher Scientific unless stated otherwise.

Hepatocyte Culture and FXR Agonist Treatment. Transporter certified cryopreserved human hepatocytes [HC3-26, HUM4122C/D, HUM4119C, and HU8246 purchased from XenoTech (Kansas City, KS), Lonza (Basel, Switzerland), and Thermo Fisher Scientific, respectively] were obtained from two Caucasian female donors, one Asian male donor, and one African American female donor, respectively (age range, 30-43 years; body mass index range, 22-39). Hepatocytes were seeded at a density of $0.4-0.5 \times 10^{6}$ cells/well in 24-well BioCoat plates and cultured in a sandwich configuration (overlaid with Matrigel) in QualGro induction medium as previously reported (Swift et al., 2010). On day 2 of culture, SCHH were treated with OCA $(1 \mu \mathrm{M})$, CDCA $(100 \mu \mathrm{M})$, or vehicle control for 72 hours. The dose of OCA was selected based on the maximum plasma concentration of OCA at steady state (approximately 0.7-1 $\mu \mathrm{M}$ ) (Edwards et al., 2016). In addition, based on the dose-gene expression relationships published previously, the maximal effect on the induction of downstream genes was achieved at $1 \mu \mathrm{M}$ OCA and $100 \mu$ M CDCA (Jackson et al., 2016; Zhang et al., 2017). Previous studies using the same lots of human hepatocytes (Jackson et al., 2016; Zhang et al., 2017), and a study using different lots of human hepatocytes (Yang et al., 2016), demonstrated that neither OCA $(1 \mu \mathrm{M})$ nor CDCA $(100 \mu \mathrm{M})$ affected the viability of SCHH. The medium was changed every 24 hours.

$d_{8}$-TCA Uptake and Efflux in SCHH. On day 5 of culture (at the end of 72-hour treatment), uptake of $d_{8}$-TCA in $\mathrm{Ca}^{2+}$-containing (standard) Hanks' balanced salt solution (HBSS) and efflux of $d_{8^{-}}$ TCA in standard and $\mathrm{Ca}^{2+}$-free HBSS was performed ( $n=3$ donors, HC3-26, HUM4122C, and HUM4119C, measured in triplicate), as described previously (Yang et al., 2015; Guo et al., 2016). Briefly, SCHH were preincubated with standard or $\mathrm{Ca}^{2+}$-free HBSS for 10 minutes Incubation with $\mathrm{Ca}^{2+}$-free HBSS disrupts the tight junctions which seal the canalicular networks, allowing the contents in the bile canaliculi to be released into the medium (B-CLEAR technology) (Liu et al., 1999). After preincubation, SCHH were dosed with $2.5 \mu \mathrm{M} d_{8}$-TCA in standard HBSS containing $4 \%$ bovine serum albumin (BSA) for 20 minutes (uptake phase). The presence of BSA (Fraction V; Thomas Scientific, Swedesboro, NJ) during the uptake phase mimics the effect of protein binding in vivo. After the uptake phase, the cells were washed for 1 minute and incubated with fresh protein-free standard or $\mathrm{Ca}^{2+}$-free HBSS for 15 minutes (efflux phase). The total amount of $d_{8}$-TCA in cells and bile (standard HBSS) and in cells $\left(\mathrm{Ca}^{2+}\right.$-free HBSS) during the uptake phase $(2,5,10$, and 20 minutes) and the efflux phase (2,5,10, and 15 minutes), and the total amount of $d_{8}$-TCA in the incubation buffer during the efflux phase $(2,5,10$, and 15 minutes) were determined by liquid chromatography-mass spectrometry as reported previously (Guo et al., 2016). 
Model-independent parameters describing the overall hepatobiliary disposition of TCA in SCHH were calculated using eqs. 1 and 2 (Liu et al., 1999; Yang et al., 2016) as well as eq. 3.

$$
\begin{gathered}
\mathrm{CL}_{\text {app,Bile }}=\frac{\text { Amount }_{\text {Cells }+ \text { Bile }}-\text { Amount }_{\text {Cells }}}{\text { Time } \times \text { Concentration }_{\text {Buffer }}} \\
\text { BEI }=\frac{\text { Amount }_{\text {Cells }+ \text { Bile }}-\text { Amount }_{\text {Cells }}}{\text { Amount }_{\text {Cells }+ \text { Bile }}} \times 100 \% \\
\text { BRI }=\frac{\text { Amount }_{\text {Buffer during efflux phase }}}{\text { Amount }_{\text {Cells }} \text { at end of } 20 \text {-min uptake }} \times 100 \%
\end{gathered}
$$

$\mathrm{CL}_{\text {app,Bile }}$ represents the in vitro apparent biliary clearance calculated at 10 minutes during the uptake phase. The biliary excretion index (BEI), determined at 10 minutes during the uptake phase, represents the fraction of compound accumulated in the bile compartment relative to the total accumulation of compound in cells and bile. The buffer recovery index (BRI), determined at 2 minutes during the efflux phase, represents the fraction of compound effluxed from cells and fluxed from bile canaliculi into the buffer relative to the total accumulation in cells at the end of the 20 -minute uptake phase.

PK Modeling of TCA Disposition in SCHH. A mechanistic PK model (scheme depicted in Fig. 1) incorporating linear clearance processes (Yang et al., 2015; Guo et al., 2016) was modified and fit to the TCA total mass-time data in cells and bile, cells, standard HBSS, and $\mathrm{Ca}^{2+}$-free HBSS using Phoenix WinNonlin 7.0 software (Certara USA Inc., Princeton, NJ). A mixed proportional and additive error model was used to account for residual error. Parameter estimates from a previous report were used as initial estimates for the control group (Guo et al., 2016). Data from the same hepatocyte donor exposed to different treatments were modeled together. Various model structures were tested. The best-fit model was selected based on Akaike's

\section{Standard HBSS}

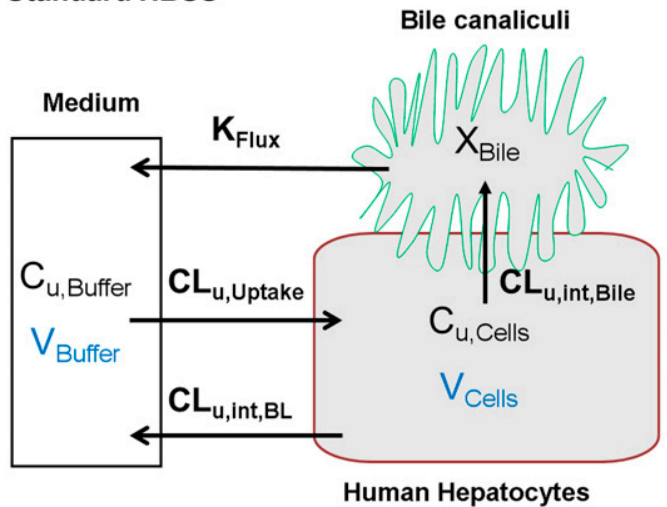

\section{$\mathrm{Ca}^{2+}$-free HBSS}

Medium

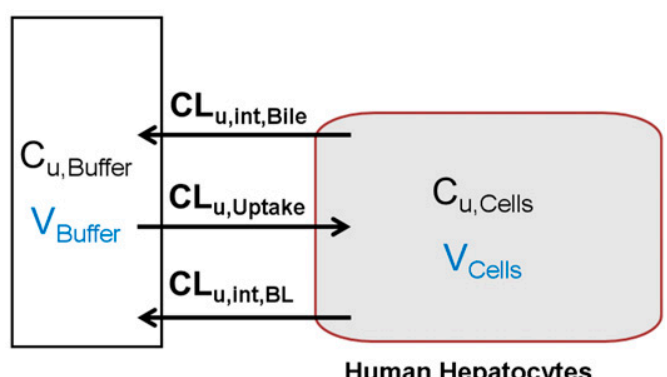

Human Hepatocytes

Fig. 1. Model structure depicting TCA disposition in SCHH in standard HBSS and $\mathrm{Ca}^{2+}$-free HBSS. $\mathrm{C}_{\mathrm{u} \text {,Cells }}$ and $\mathrm{C}_{\mathrm{u}, \mathrm{Buffer}}$ represent the unbound concentration in the cells and buffer, respectively. $\mathrm{X}_{\mathrm{Bile}}$ represents the amount in the bile canalicular compartment. information criterion, the precision of parameter estimates, the degree of bias in the residual error, and visual inspection of the predicted curves relative to the observed data. The following kinetic parameters were estimated: total uptake clearance $\left(\mathrm{CL}_{\mathrm{Uptake}}\right)$, total intrinsic basolateral efflux clearance $\left(\mathrm{CL}_{\mathrm{int}, \mathrm{BL}}\right)$, total intrinsic biliary clearance $\left(\mathrm{CL}_{\text {int,Bile }}\right)$, and the rate constant describing flux from bile networks into the medium $\left(K_{\text {Flux }}\right)$ due to periodic contraction of bile canalicular networks (Oshio and Phillips, 1981; Lee et al., 2010). The mean values and coefficient of variation $(\mathrm{CV} \%)$ of parameter estimates from the three donors were calculated. Differential eqs. 4-8 were used to describe the changes in the amount of TCA with respect to time in different compartments in this model:

Mass in standard HBSS:

$$
\begin{aligned}
\frac{\mathrm{dX}_{\mathrm{t}, \text { Buffer }}^{+}=}{\mathrm{dt}}= & \mathrm{CL}_{\mathrm{u}, \text { int }, \mathrm{BL}} \times C_{\mathrm{t}, \text { Cells }}^{+} \times \mathrm{f}_{\mathrm{u}, \text { cell }}+K_{\text {Flux }} \times \mathrm{X}_{\mathrm{t}, \text { Bile }} \\
& -\mathrm{CL}_{\mathrm{u}, \text { Uptake }} \times C_{\mathrm{t}, \text { Buffer }}^{+} \times \mathrm{f}_{\mathrm{u}, \text { buffer }}-K_{\text {Wash }} \times \mathrm{X}_{\mathrm{t}, \text { Buffer }}^{+} \\
& \mathrm{X}_{\text {Buffer }}^{+}=\mathrm{X}_{\text {dose }}
\end{aligned}
$$

Mass in $\mathrm{Ca}^{2+}$-free HBSS:

$$
\begin{aligned}
\frac{\mathrm{dX}_{\mathrm{t}, \text { Buffer }}^{-}=}{\mathrm{dt}} & \left(\mathrm{CL}_{\mathrm{u}, \text { int,BL}}+\mathrm{CL}_{\mathrm{u}, \text { int,Bile }}\right) \times C_{\mathrm{t}, \text { Cells }}^{-} \times \mathrm{f}_{\mathrm{u}, \text { cell }} \\
& -\mathrm{CL}_{\mathrm{u}, \text { Uptake }} \times C_{\mathrm{t}, \text { Buffer }}^{-} \times \mathrm{f}_{\mathrm{u}, \text { buffer }}-K_{\text {Wash }} \times \mathrm{X}_{\mathrm{t}, \text { Buffer }}^{-} \\
& \mathrm{X}_{\text {Buffer }}^{-} \stackrel{\circ}{\circ}=\mathrm{X}_{\text {dose }}
\end{aligned}
$$

Mass in Cells:

$$
\begin{aligned}
\frac{\mathrm{dX}_{\mathrm{t}, \text { Cells }}^{+ \text {or }}=}{\mathrm{dt}}= & \mathrm{CL}_{\mathrm{u}, \text { Uptake }} \times C_{\mathrm{t}, \text { Buffer }}^{+ \text {or- }} \times \mathrm{f}_{\mathrm{u}, \text { buffer }} \\
& -\left(\mathrm{CL}_{\mathrm{u}, \text { int }, \mathrm{BL}}+\mathrm{CL}_{\mathrm{u}, \text { int }, \text { Bile }}\right) \times C_{\mathrm{t}, \text { Cells }}^{+ \text {or- }} \times \mathrm{f}_{\mathrm{u}, \text { cell }} \\
& \mathrm{X}_{\text {Cells }}^{+ \text {or }}{ }^{\circ}=0
\end{aligned}
$$

Mass in Bile (standard HBSS):

$$
\begin{aligned}
\frac{\mathrm{dX}_{\mathrm{t}, \text { Bile }}}{\mathrm{dt}}= & \mathrm{CL}_{\mathrm{u}, \text { int,Bile }} \times C_{\mathrm{t}, \text { Cells }}^{+} \times \mathrm{f}_{\mathrm{u}, \text { cell }} \\
& -\mathrm{K}_{\text {Flux }} \times \mathrm{X}_{\mathrm{t}, \text { Bile }} \\
& \mathrm{X}_{\text {Bile }}^{\circ}=0
\end{aligned}
$$

Mass in Cells + Bile (standard HBSS):

$$
\begin{gathered}
\frac{\mathrm{dX}_{\mathrm{t}, \text { Cells }+ \text { Bile }}}{\mathrm{dt}}=\frac{\mathrm{dX}_{\mathrm{t}, \text { Bile }}}{\mathrm{dt}}+\frac{\mathrm{dX}_{\mathrm{t}, \text { Cells }}^{+}}{\mathrm{dt}} \\
\mathrm{X}_{\text {Cells }+ \text { Bile }}^{\circ}=0
\end{gathered}
$$

where $C_{\mathrm{t}, \text { Cells }}$ represents the total intracellular concentration and was calculated as $\mathrm{X}_{\mathrm{t}, \text { Cells }} / V_{\text {Cells. }}$. $V_{\text {Cells }}$ represents cellular volume and was calculated and fixed using the protein content of each hepatocyte preparation and a value of $7.4 \mu \mathrm{l} / \mathrm{mg}$ protein (Pfeifer et al., 2013; Yang et al., 2015). Superscripted plus and minus signs refer to $\mathrm{Ca}^{2+}$-containing (standard HBSS) and $\mathrm{Ca}^{2+}$-free HBSS, respectively. $\mathrm{X}_{\mathrm{t}, \text { Cells }}, \mathrm{X}_{\mathrm{t}}$, Cells+Bile, and $\mathrm{X}_{\mathrm{t}, \mathrm{Bile}}$ represent the total amount in cells, cells and bile, and bile, respectively. $C_{\mathrm{t}, \mathrm{Buffer}}$ represents the total concentration in buffer. $V_{\text {Buffer }}$ was set as a constant $(0.3 \mathrm{ml}) . \mathrm{CL}_{\mathrm{u}, \text { Uptake }}$ represents unbound uptake clearance. $\mathrm{CL}_{\mathrm{u}, \mathrm{int}, \mathrm{BL}}$ represents unbound intrinsic basolateral efflux clearance. $\mathrm{CL}_{\mathrm{u} \text {,int,Bile }}$ represents unbound intrinsic biliary clearance. $f_{u, b u f f e r}$ represents the unbound fraction in buffer containing $4 \% \mathrm{BSA} ; \mathrm{f}_{\mathrm{u} \text {,buffer }}$ was set at 0.15 (Wolf et al., 2008) during the 20-minute uptake phase and was set at 1 during the 15-minute efflux phase because BSA was present only in the uptake phase. $f_{u, c e l l}$ represents the unbound fraction in hepatocytes and was assumed to be 0.15. $\mathrm{CL}_{\text {Uptake }}$ was calculated as $\mathrm{f}_{\mathrm{u} \text {,buffer }} \times \mathrm{CL}_{\mathrm{u} \text {,Uptake }} ; \mathrm{CL}_{\text {int,BL }}$ and $\mathrm{CL}_{\text {int,Bile }}$ were calculated as $\mathrm{f}_{\mathrm{u} \text {,cell }} \times \mathrm{CL}_{\mathrm{u} \text {,int,BL }}$ and $\mathrm{f}_{\mathrm{u} \text {,cell }} \times \mathrm{CL}_{\mathrm{u} \text {,int,Bile }}$, respectively. To mimic the 1 -minute wash between the uptake and efflux phase, $K_{\text {Wash }}$ was activated for 1 minute using an if-then 
statement. $K_{\text {Wash }}$ was fixed at $5 \times 10^{4} \mathrm{~min}^{-1}$, which was sufficient to eliminate the $d_{8}$-TCA from the buffer compartment. Protein concentrations were measured by the bicinchoninic acid assay.

Immunoblots. At the end of 72-hour treatment (day 5 cultures), SCHH ( $n=3$ hepatocyte donors, HUM4122D, HC3-26, and HU8246) were washed with PBS, and the membrane protein was extracted using the ProteoExtract Native Membrane Protein Extraction Kit (Millipore Sigma, Burlington, MA). Membrane proteins (12 $\mu \mathrm{g}$, without boiling) were mixed with loading buffer containing $50 \mathrm{mM}$ dithiothreitol and resolved on NuPAGE 4\%-12\% Bis-Tris gel or 7\% Tris-acetate gel and the proteins were transferred to polyvinylidene fluoride membranes. After blocking in 5\% nonfat milk in Tris-buffered saline with Tween 20 for 1 hour, blots were incubated with the following primary antibodies diluted in 5\% BSA (Sigma-Aldrich, St. Louis, MO): OST $\alpha$, (1:500), OST $\beta$ (1:500), MRP3 (1:1000), MRP4 (1:200), BSEP (1:1000), and NTCP (1:1500) overnight at $4^{\circ} \mathrm{C}$ or with primary antibody for ATPase (1:500) for 3 hours at room temperature. Then the blots were probed with horseradish peroxidase-conjugated anti-rabbit (OSTs, BSEP, MRP3, NTCP, ATPase) or anti-goat IgG secondary antibody (MRP4) for 1 hour at room temperature (1:7000). Signals were detected by using the Amersham ECL Select Western Blotting Detection Reagent (GE Healthcare Bio-Sciences, Pittsburgh, PA) or Clarity Max ECL Substrate (Bio-Rad) with a Bio-Rad ChemiDoc XRS+ system. Densitometric analysis was performed using ImageJ 1.6.0 software (National Institutes of Health, Bethesda, MD).

Data Analysis. Statistical analysis was performed on the clearance values and immunoblot results using GraphPad Prism software (version 6.01; GraphPad Software Inc., La Jolla, CA). One-way analysis of variance with Bonferroni's test was used to correct for multiple comparisons with the control group.

\section{Results}

Uptake and Efflux of $d_{8}$-TCA in SCHH. OCA and CDCA treatment markedly decreased the total amount of TCA in hepatocytes, the hepatocyte plus bile compartment, and the efflux buffer (Fig. 2). The BRI (\%), representing the fraction of accumulated TCA in hepatocytes that undergoes efflux into buffer, was increased from $27 \%-36 \%$ in the control to $50 \%-53 \%$ and $47 \%-78 \%$ in OCA- and CDCA-treated SCHH, respectively. The $\mathrm{CL}_{\mathrm{app}, \mathrm{Bile}}$ of TCA ranged from 0.62 to 1.2 $\mu \mathrm{l} / \mathrm{min}$ per milligram protein in control $\mathrm{SCHH}$ but was decreased to $0.35-0.81$ and $0.097-0.41 \mu \mathrm{l} / \mathrm{min}$ per milligram protein by OCA and CDCA treatment, respectively. However, the BEI (\%) in control SCHH $(63 \%-71 \%)$ was similar to values after OCA (63\%-74\%) and CDCA (46\%-71\%) treatment.

PK Modeling of $d_{8}$-TCA Disposition in SCHH. Observed mass-time profiles of TCA from individual donors were plotted against the predicted mass-time profiles generated by using the best-fit parameters based on the mechanistic model (Fig. 2). The estimated clearance values of TCA in individual hepatocyte donors and the mean values calculated from the individual donors are presented in Table 1 . The mechanistic model revealed that $\mathrm{CL}_{\text {int,Bile }}$ was approximately 3 -fold higher than $\mathrm{CL}_{\text {int,BL }}$ in the control hepatocytes, consistent with a previous report (Guo et al., 2016). The CV\% of the estimated parameters from model fitting were acceptable $(<65 \%$; Table 1), indicating good precision of the model fitting. The fold change in each parameter in treated hepatocytes compared with control hepatocytes is shown in Fig. 3. OCA and CDCA treatment significantly increased $\mathrm{CL}_{\text {int,BL }}$ by $>6$-fold and $\mathrm{CL}_{\text {int,Bile }}$ by approximately 2 -fold. Changes in $\mathrm{CL}_{\text {Uptake }}$ were not statistically significant.
Protein Expression of TCA Transporters. To investigate which transporters might have contributed to the changes in TCA disposition, immunoblot analysis of major bile acid transporters was performed using SCHH from three hepatocyte donors. As shown in Fig. 4, OCA treatment increased the average expression of OST $\alpha$ and OST $\beta$ to $260 \%$ and $1100 \%$ of the control, respectively. CDCA treatment increased the average expression of OST $\alpha$ and OST $\beta$ to $280 \%$ and $1300 \%$ of the control, respectively. The average BSEP expression was modestly upregulated to $185 \%$ and $165 \%$ of the control by OCA and CDCA. Changes in MRP3, MRP4, and NTCP protein expression were negligible $(<25 \%$ changes $)$. The changes in OST $\alpha$ and OST $\beta$ expression were statistically significant, whereas the changes in other proteins were inconclusive.

\section{Discussion}

To our knowledge, this study is the first direct demonstration of functional induction of bile acid efflux transporters in response to FXR agonists, revealed by mechanistic PK modeling results. The combination of mechanistic PK modeling and molecular analysis provided a comprehensive data set for understanding the mechanisms of OCA- and CDCA-mediated alterations in hepatic bile acid transporters. Increases in the basolateral efflux clearance and biliary clearance were consistent with a pronounced upregulation of OST $\beta$ protein expression and a smaller increase in BSEP protein expression, respectively (Fig. 5).

This study demonstrated the advantages of PK modeling in assessing changes in concurrent clearance pathways in a whole cell system. Quantitative assessment of basolateral bile acid efflux transporter function is challenging, since plasma or medium bile acid concentrations reflect the net effect of synthesis and metabolism as well as uptake and efflux. A recent report quantified the transport kinetics of a bile acid tracer $\left[N\right.$-methyl $\left.-{ }^{11} \mathrm{C}\right]$ cholylsarcosine, which is similar to glycocholic acid, in human blood and liver using positron emission tomography (Orntoft et al., 2017). Based on a kinetic model, the rate constant for basolateral efflux of [ $N$-meth$\left.\mathrm{yl}-{ }^{11} \mathrm{C}\right]$ cholylsarcosine was higher in cholestatic patients compared with healthy subjects. Similarly, in this mechanistic PK modeling study, concurrent clearance pathways of TCA in hepatocytes were deconvoluted; $\mathrm{CL}_{\text {int,BL }}$ and $\mathrm{CL}_{\text {int,Bile }}$ of TCA were increased by FXR agonist treatment. This information may have been overlooked by merely calculating modelindependent parameters. Although BRI showed a 2-fold increase, indicating increased basolateral efflux, it underestimated the magnitude of change compared with the modelestimated 6-fold increase in $\mathrm{CL}_{\mathrm{int}, \mathrm{BL}}$. After FXR agonist treatment, $\mathrm{BEI}$ remained the same and $\mathrm{CL}_{\mathrm{app} \text {,Bile }}$ decreased, whereas model-estimated $\mathrm{CL}_{\text {int,Bile }}$ increased by 2 -fold. In this case, $\mathrm{BEI}$ and $\mathrm{CL}_{\mathrm{app}, \mathrm{Bile}}$ measured at a single time point failed to reflect the modest changes in biliary excretion because these model-independent parameters are also affected by basolateral uptake and efflux.

The FXR agonist-induced changes in transporter protein expression (greater induction of OST $\beta$ and OST $\alpha$ than BSEP) were consistent with the increases in TCA clearance (greater increase in $\mathrm{CL}_{\text {int,BL }}$ than $\mathrm{CL}_{\text {int,Bile }}$ ), which would be expected for plasma membrane-localized proteins. In addition, alterations in protein expression agreed with previously published 
HUM4119C
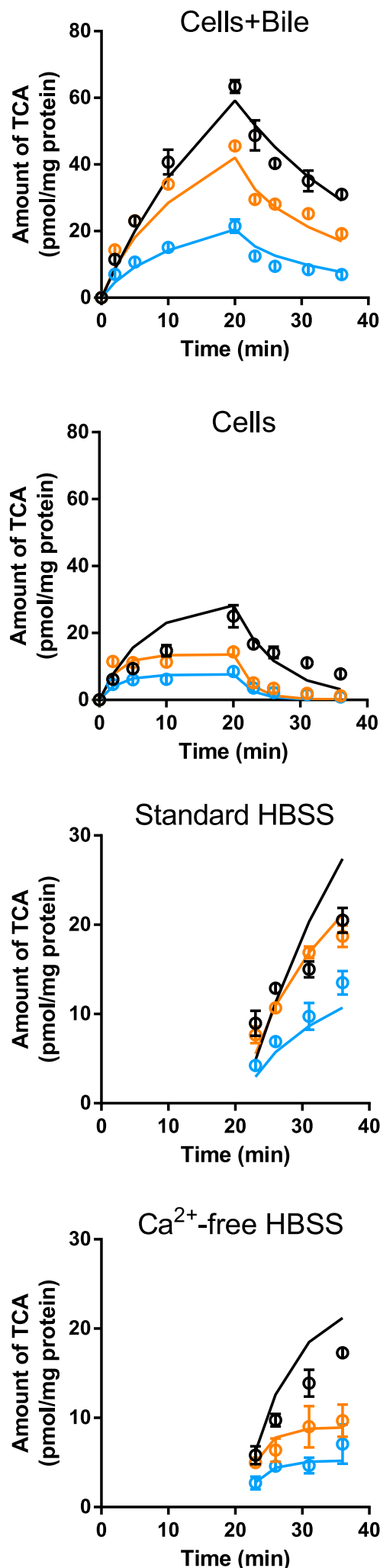

HUM4122C

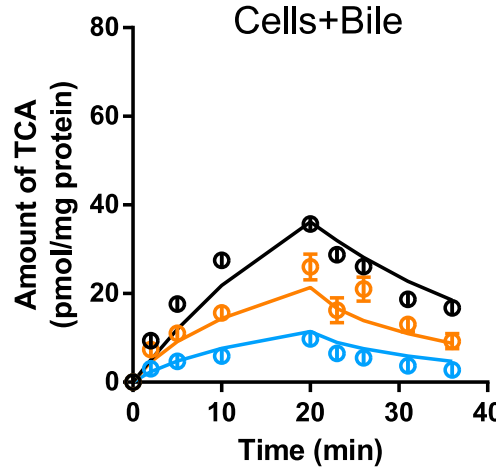

Cells
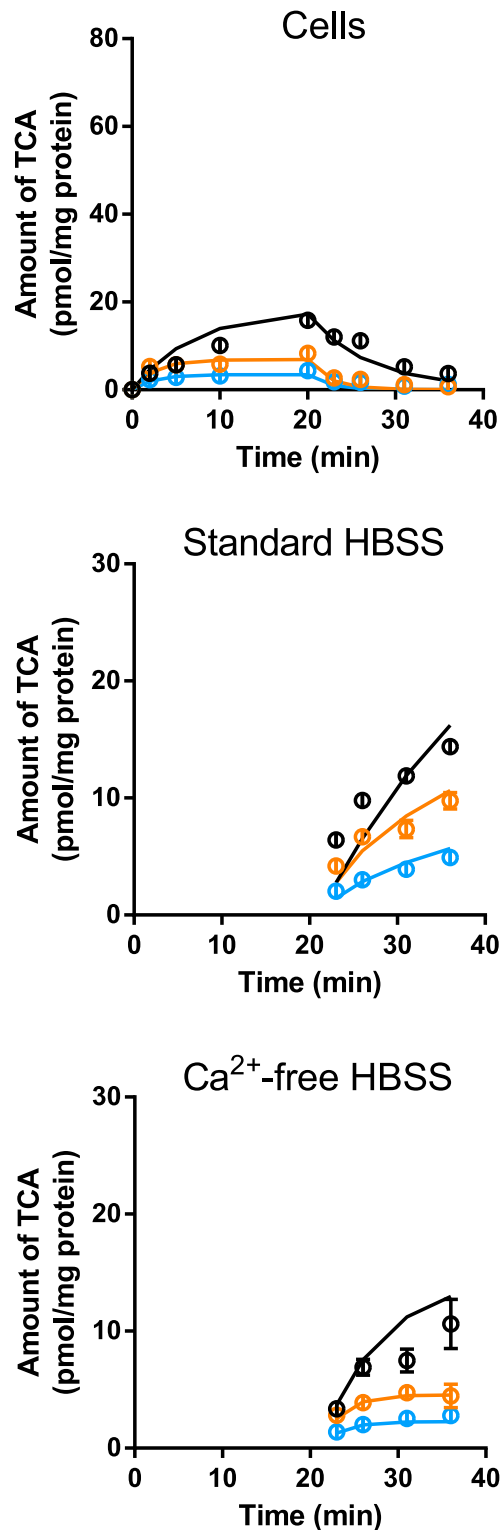

HC3-26

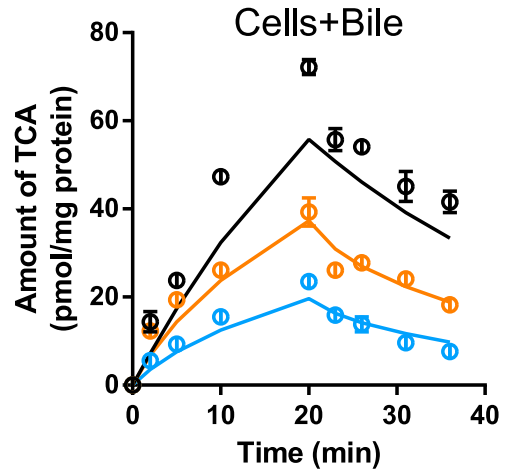

Cells
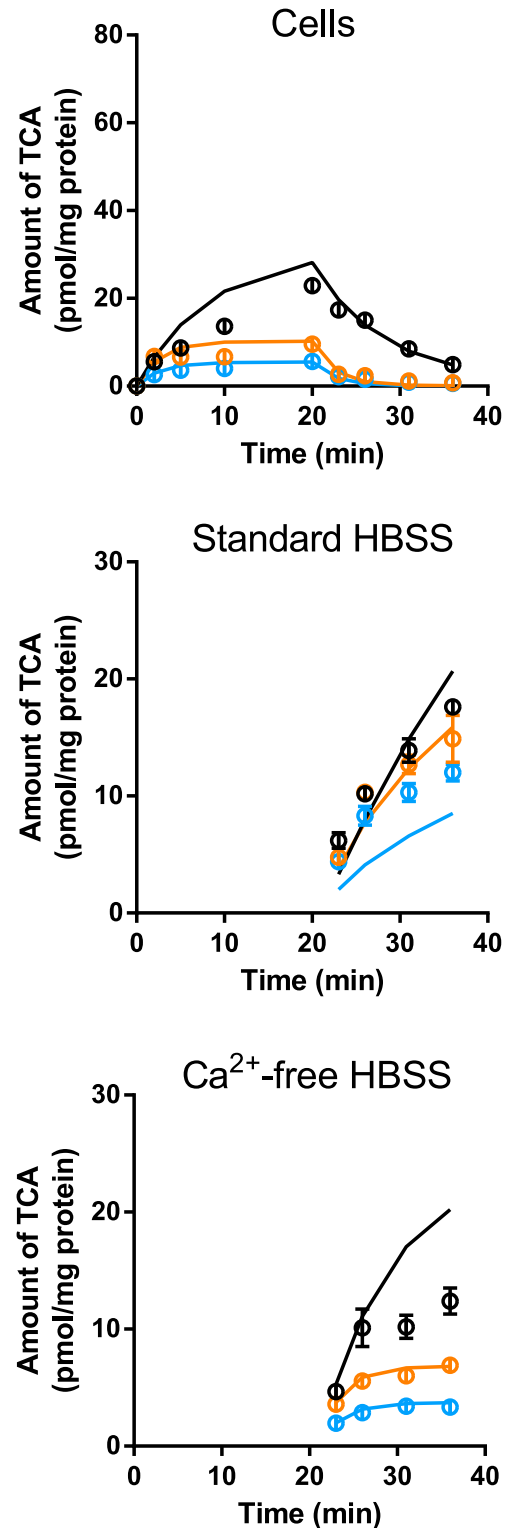

Fig. 2. Predicted and observed amount of TCA in different matrices from three different SCHH donors. Black, orange, and blue represent the control-, OCA-, and CDCA-treated groups, respectively, for observed (circles) and predicted (solid lines) data. Experimental data represent the mean \pm S.D. (triplicate measurements). The fitted mass versus time profiles were generated from eqs. 4-8, and the parameter estimates are reported in Table 1. 
TABLE 1

Parameter estimates of TCA $\mathrm{CL}_{\text {int,BL }}, \mathrm{CL}_{\text {int,Bile }}, \mathrm{CL}_{\mathrm{Uptake}}$, and $\mathrm{K}_{\text {Flux }}$

\begin{tabular}{|c|c|c|c|c|c|c|c|c|c|}
\hline \multirow{2}{*}{ Treatment } & \multirow{2}{*}{ Donor } & \multicolumn{2}{|c|}{$\mathrm{CL}_{\text {int,BL }}$} & \multicolumn{2}{|c|}{$\mathrm{CL}_{\text {int,Bile }}$} & \multicolumn{2}{|c|}{$\mathrm{CL}_{\text {Uptake }}$} & \multicolumn{2}{|c|}{$K_{\text {Flux }}$} \\
\hline & & Estimate & $\mathrm{CV} \%$ & Estimate & $\mathrm{CV} \%$ & Estimate & $\mathrm{CV} \%$ & Estimate & $\mathrm{CV} \%$ \\
\hline & & \multicolumn{6}{|c|}{$\mu l /$ min per milligram protein } & \multicolumn{2}{|c|}{$\min ^{-1}$} \\
\hline \multirow[t]{4}{*}{ Control } & 1 & 0.29 & 33 & 0.80 & 14 & 1.6 & 6.4 & 0.048 & 7.3 \\
\hline & 2 & 0.25 & 52 & 0.80 & 15 & 0.95 & 5.8 & 0.046 & 12 \\
\hline & 3 & 0.19 & 58 & 0.70 & 16 & 1.4 & 4 & 0.037 & 11 \\
\hline & Mean & 0.24 & N/A & 0.77 & N/A & 1.3 & N/A & 0.044 & N/A \\
\hline \multirow[t]{4}{*}{ OCA } & 1 & 1.7 & 32 & 1.3 & 12 & 1.9 & 18 & $0.048^{a}$ & N/A \\
\hline & 2 & 1.6 & 41 & 1.3 & 14 & 1.04 & 24 & $0.046^{a}$ & N/A \\
\hline & 3 & 1.4 & 38 & 1.5 & 12 & 1.54 & 17 & $0.037^{a}$ & N/A \\
\hline & Mean & 1.6 & N/A & 1.4 & N/A & 1.5 & N/A & $0.044^{a}$ & N/A \\
\hline \multirow[t]{4}{*}{ CDCA } & 1 & 1.7 & 40 & 1.1 & 16 & 1.03 & 25 & $0.048^{a}$ & N/A \\
\hline & 2 & 1.6 & 64 & 1.4 & 24 & 0.54 & 36 & $0.046^{a}$ & N/A \\
\hline & 3 & 1.3 & 56 & 1.5 & 24 & 0.79 & 24 & $0.037^{a}$ & N/A \\
\hline & Mean & 1.6 & N/A & 1.3 & N/A & 0.78 & N/A & $0.044^{a}$ & N/A \\
\hline
\end{tabular}

Mean values of these three individual estimates were calculated. Estimates and the corresponding CV\% values were obtained by fitting the model to the time-course data from individual SCHH preparations (Fig. 2) based on the model scheme depicted in Fig. 1. Donors 1, 2, and 3 represent HUM4119C, HUM4122C, and HC3-26, respectively. N/A, not applicable.

${ }^{a} K_{\text {Flux }}$ values in treated SCHH were fixed to the values in control SCHH from the same hepatocyte donor.

gene expression data in SCHH. OCA treatment $(1 \mu \mathrm{M}$, 72 hours) increased OST $\alpha$, OST $\beta$, and BSEP mRNA in SCHH by 6.4-, 43-, and 4.6-fold, respectively (Zhang et al., 2017), while CDCA treatment (100 $\mu \mathrm{M}, 72$ hours) increased OST $\alpha$, OST $\beta$, and BSEP mRNA by 3.1-, 21-, and 2.2-fold, respectively (Jackson et al., 2016). No marked changes in the mRNA expression of MRP3, MRP4, or NTCP were observed in previous studies (Jackson et al., 2016; Zhang et al., 2017), consistent with the present protein expression data. Therefore, the increase in bile acid efflux was likely due to the induction of OST $\beta$ and to a lesser extent to OST $\alpha$ induction. Protein expression of NTCP remained unchanged in FXR agonist-treated SCHH, consistent with no statistically significant changes in $\mathrm{CL}_{\mathrm{Uptake}}$ in CDCA-treated SCHH.

OST $\alpha / \beta$ is expressed in many other organs, including the intestine, kidneys, and testis, and it can transport a variety of endogenous compounds in addition to bile acids, such as estrone 3-sulfate, prostaglandin $\mathrm{E}$, dehydroepiandrosterone 3-sulfate, and drugs like digoxin (Soroka et al., 2010). Therefore, upregulation of OST $\alpha$ and OST $\beta$ may affect the disposition of various endogenous and exogenous compounds and may have significant physiologic implications and affect pharmacotherapy. The heterodimeric $\mathrm{OST} \alpha / \beta$ is a facilitated transporter that can translocate organic solutes across the basolateral membrane in either direction in vitro (Ballatori et al., 2005). In vivo, it is the primary bile acid efflux transporter in the intestine (Soroka et al., 2010). Lower expression of OST $\alpha$ and OST $\beta$ in transfected COS cells decreased OST $\alpha / \beta$-mediated transport (Sultan et al., 2017). OST $\beta$ is required for the maturation and stability of OST $\alpha$ (Dawson et al., 2010). The baseline gene expression level of OST $\alpha$ is 3- to 7 -fold higher than OST $\beta$ in human liver tissue (Ballatori et al., 2005, 2009). Since heterodimerization of the two subunits is required for transport function, greater induction of OST $\beta$ might be needed for maximal function of OST $\alpha / \beta$. Like other basolateral efflux transporters, OST $\alpha / \beta$ is expressed at much lower levels in healthy human hepatocytes. Under cholestatic conditions, basolateral efflux transporters are often upregulated to serve as alternate excretory pathways for bile acids (Zollner et al., 2003; Chai et al., 2012). In this study, OCA and CDCA treatment both increased the $\mathrm{CL}_{\text {int,BL }}$ of TCA more than 6 -fold relative to control, resulting in clearance values that were slightly greater than the $\mathrm{CL}_{\text {int,Bile }}$. An increase in $\mathrm{CL}_{\text {int,BL }}$ may exert a hepatoprotective effect by decreasing the hepatocellular accumulation of bile acids.
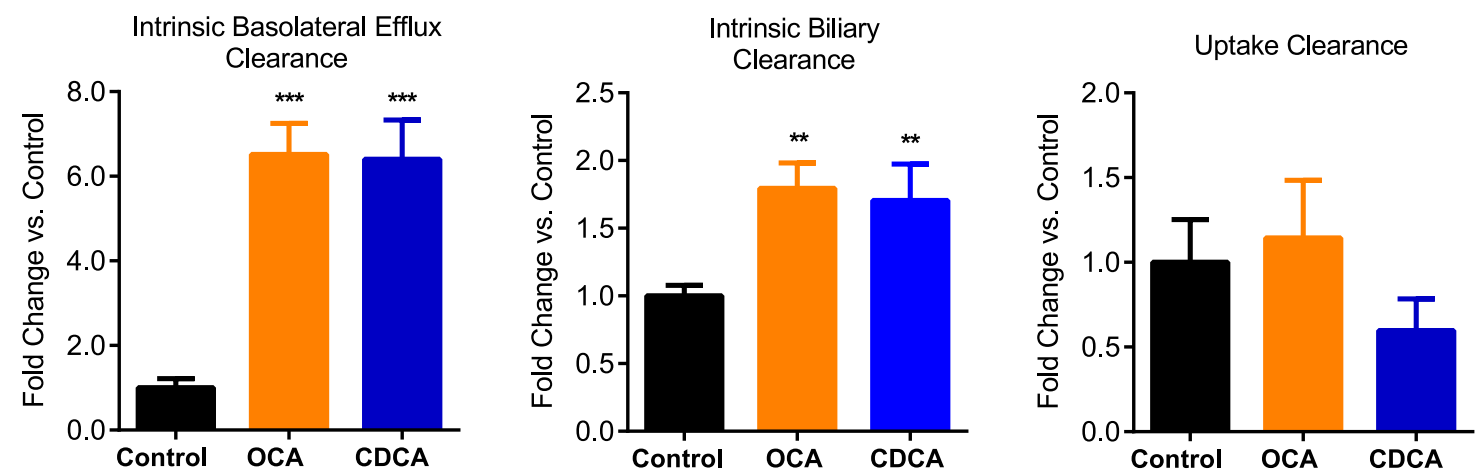

Fig. 3. Fold change in $\mathrm{CL}_{\text {int,BL}}, \mathrm{CL}_{\text {int,Bile }}$, and $\mathrm{CL}_{\mathrm{Uptake}}$ in OCA- and CDCA-treated SCHH compared with the control. Data represent the mean \pm S.D. $(n=3$ hepatocyte donors, as detailed in Table 1$)$. ${ }^{* * P} P<0.01 ; * * P<0.001$ (treated vs. control). 


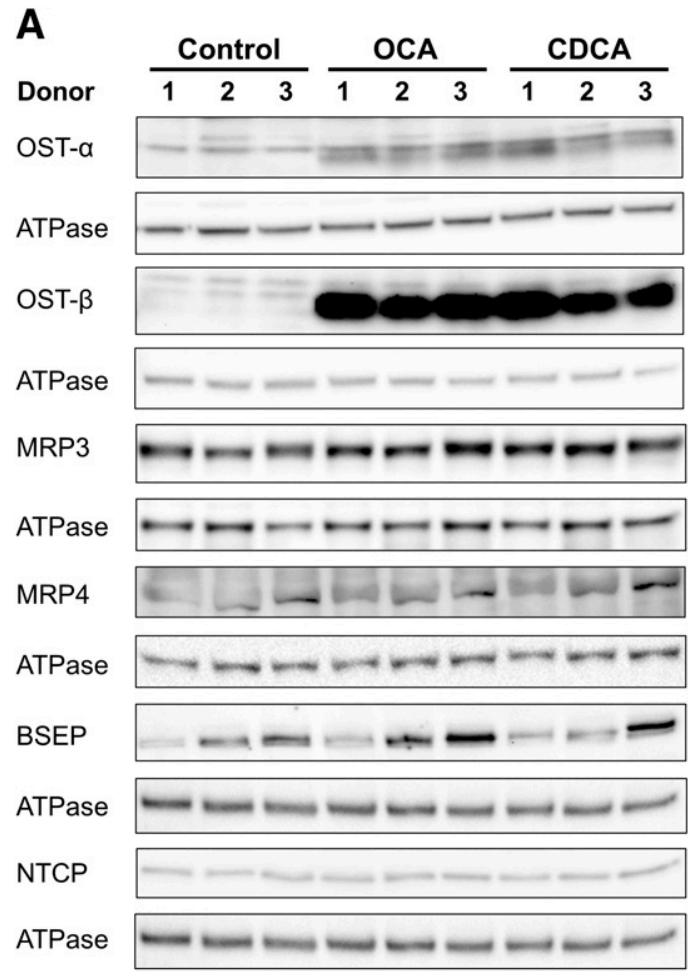

B
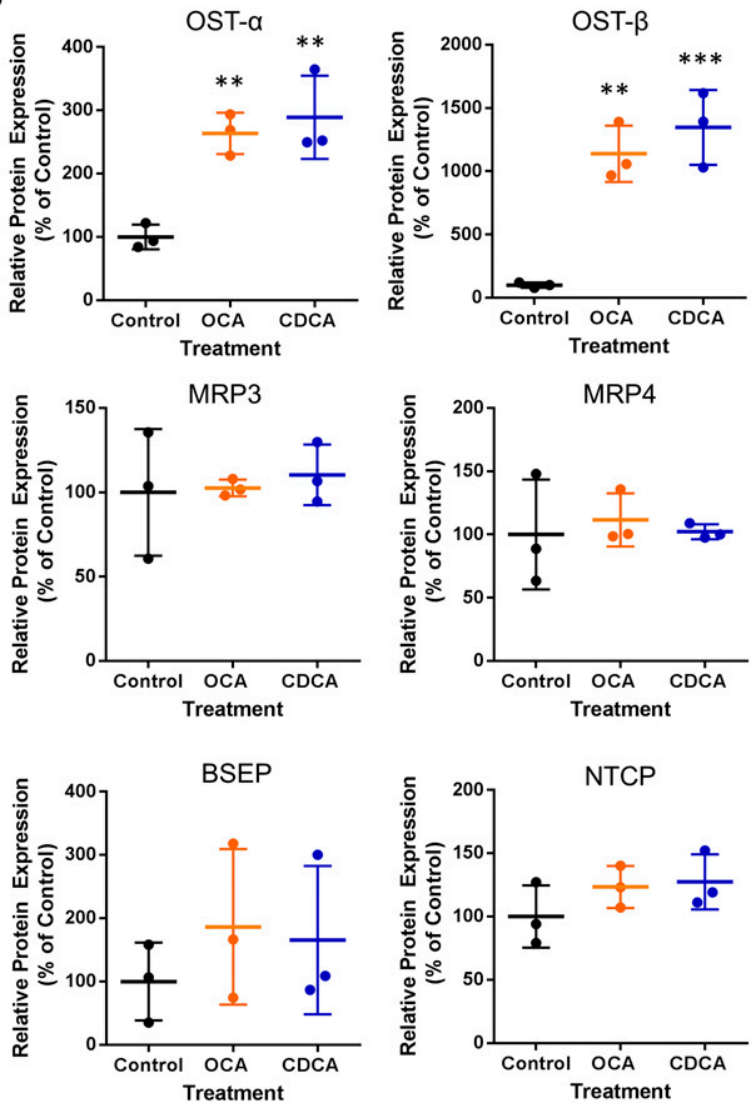

Fig. 4. Effect of OCA and CDCA treatment of SCHH on the protein expression of OST $\alpha$, OST $\beta$, MRP3, MRP4, BSEP, and NTCP. (A) Immunoblots from three independent studies using three hepatocyte donors are shown. ATPase was used as the loading control for each blot. Donors 1,2 , and 3 represent HU8246, HUM4122D, and HC3-26, respectively. Each protein was analyzed on a separate membrane except that BSEP and NTCP shared the same membrane and the same ATPase bands. (B) Quantitative analyses conducted by calculating the relative densities of each protein normalized by the density of ATPase (mean \pm S.D. expressed as the percentage of the control; $n=3$ hepatocyte donors). $* * P<0.01 ; * * * P<0.001$ (treated vs. control).

The marked induction of OST $\alpha$, OST $\beta$, and, to a lesser extent, BSEP, but not MRP3, MRP4, or NTCP, as shown by immunoblotting, could be explained by the differential regulatory mechanisms of these transporters. SLC51A, SLC51B (genes encoding OST $\alpha$ and OST $\beta$, respectively), and $A B C B 11$ (gene encoding BSEP) are direct target genes for FXR (Ananthanarayanan et al., 2001; Yu et al., 2002; Landrier et al., 2006; Lee et al., 2006; Lefebvre et al., 2009). The FXR pathway was functional in SCHH and activated by OCA $(1 \mu \mathrm{M})$ and CDCA $(100 \mu \mathrm{M})$ treatment, as shown by the following changes in other FXR target genes: decreased gene expression of CYP7A1, the synthesizing enzyme for bile acids, and increased gene expression of a small heterodimer partner (Jackson et al., 2016; Zhang et al., 2017), similar to findings reported by Liu et al. (2014). However, MRP3 is regulated by the retinoic acid receptor, pregnane $\mathrm{X}$ receptor, constitutive androstane receptor, and liver receptor homolog-1 (Inokuchi et al., 2001; Teng et al., 2003; Chen et al., 2007; Geier et al., 2007). MRP4 is regulated primarily by the constitutive androstane receptor (Assem et al., 2004; Geier et al., 2007). Although rat Ntcp is a target gene of FXR (Denson et al., 2001), gene expression of human NTCP was minimally affected by FXR agonists. Gene expression of NTCP remained unchanged in human liver slices after CDCA treatment (100 $\mu \mathrm{M}, 24$ hours) (Jung et al., 2007) and in SCHH after CDCA ( $100 \mu \mathrm{M}, 72$ hours) and OCA treatment ( $1 \mu \mathrm{M}, 72$ hours $)$
(Jackson et al., 2016; Zhang et al., 2017). A slight decrease $(30 \%)$ in NTCP mRNA was reported in human hepatocytes after CDCA treatment (100 $\mu \mathrm{M}, 48$ hours) (Liu et al., 2014). Our results, together with these literature reports, showed that NTCP protein expression and function do not appear to be

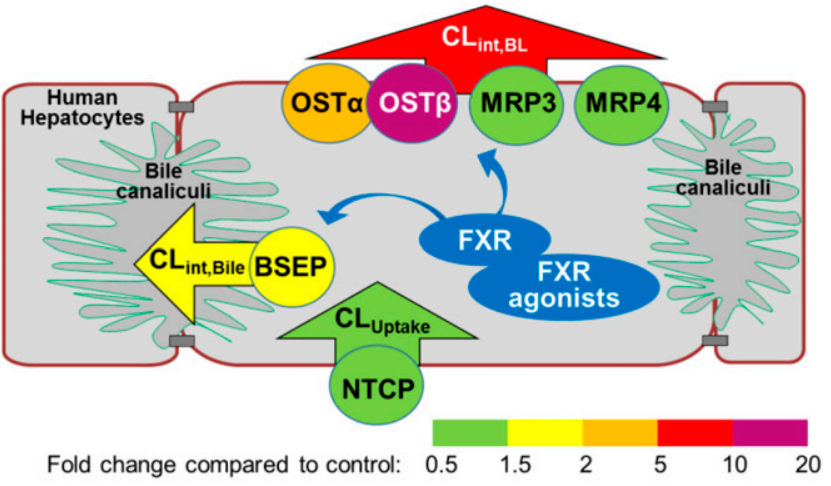

Fig. 5. The effect of FXR agonists on bile acid clearance and protein expression of bile acid transporters in SCHH. Different colors represent the fold change in clearance values (arrowheads; $\mathrm{CL}_{\mathrm{Uptake}}, \mathrm{CL}_{\mathrm{int}, \mathrm{BL}}$, and $\mathrm{CL}_{\text {int,Bile }}$ ) and protein levels of transporters (circles; OST $\alpha / \beta, \mathrm{MRP} 3$, MRP4, BSEP, and NTCP). 
markedly affected by OCA and CDCA treatment of SCHH at the concentrations used in our study.

One assumption of the current PK model was that $K_{\text {Flux }}$ was the same across different treatment groups. $K_{\text {Flux }}$ is dependent on the contraction of bile canaliculi driven by the actin network (Watanabe et al., 1985). Since there is no evidence that FXR regulates actin function, $K_{\text {Flux }}$ was fixed to control values to avoid overparameterization.

In conclusion, FXR agonists OCA and CDCA increased bile acid efflux in $\mathrm{SCHH}$, which contributed to reduced hepatocellular concentrations of $d_{8}$-TCA. OST $\alpha / \beta$ appeared to be the major transporter responsible for the increase in intrinsic basolateral efflux clearance of $d_{8}$-TCA. These cellular effects, together with the suppression of bile acid synthesis (Jackson et al., 2016; Zhang et al., 2017), provide the mechanistic rationale for FXR as a therapeutic target for the treatment of cholestatic diseases by reducing bile acid burden in hepatocytes. These results will enhance our understanding of the FXR-dependent mechanisms of OCA and its impact on bile acid homeostasis.

\section{Acknowledgments}

We acknowledge Kimberly M. Freeman for her assistance with the hepatocyte experiments. We thank Drs. Jonathan P. Jackson, Dong $\mathrm{Fu}$, and Melina Malinen for valuable scientific input in the preparation of this manuscript, and Dr. Jacqueline Bezençon for her expertise with immunoblot analysis.

\section{Authorship Contributions}

Participated in research design: Guo, Edwards, K. R. Brouwer, K. L. R. Brouwer.

Conducted experiments: Guo.

Performed data analysis: Guo, LaCerte, Edwards, K. R. Brouwer,

K. L. R. Brouwer.

Wrote or contributed to the writing of the manuscript: Guo, Edwards, K. R. Brouwer, LaCerte, K. L. R. Brouwer.

\section{References}

Adorini L, Pruzanski M, and Shapiro D (2012) Farnesoid X receptor targeting to treat nonalcoholic steatohepatitis. Drug Discov Today 17:988-997.

Ahlin G, Hilgendorf C, Karlsson J, Szigyarto CA, Uhlén M, and Artursson P (2009) Endogenous gene and protein expression of drug-transporting proteins in cell lines routinely used in drug discovery programs. Drug Metab Dispos 37:2275-2283.

Allen K, Jaeschke H, and Copple BL (2011) Bile acids induce inflammatory genes in hepatocytes: a novel mechanism of inflammation during obstructive cholestasis. Am J Pathol 178:175-186.

Ananthanarayanan M, Balasubramanian N, Makishima M, Mangelsdorf DJ, and Suchy FJ (2001) Human bile salt export pump promoter is transactivated by the farnesoid X receptor/bile acid receptor. J Biol Chem 276:28857-28865.

Assem M, Schuetz EG, Leggas M, Sun D, Yasuda K, Reid G, Zelcer N, Adachi M, Strom S, Evans RM, et al. (2004) Interactions between hepatic Mrp4 and Sult2a as revealed by the constitutive androstane receptor and Mrp4 knockout mice. J Biol Chem 279:22250-22257.

Ballatori N, Christian WV, Lee JY, Dawson PA, Soroka CJ, Boyer JL, Madejczyk MS, and $\mathrm{Li} \mathrm{N}$ (2005) OSTalpha-OSTbeta: a major basolateral bile acid and steroid transporter in human intestinal, renal, and biliary epithelia. Hepatology 42 1270-1279.

Ballatori N, Fang F, Christian WV, Li N, and Hammond CL (2008) Ostalpha-Ostbeta is required for bile acid and conjugated steroid disposition in the intestine, kidney, and liver. Am J Physiol Gastrointest Liver Physiol 295:G179-G186.

Ballatori N, Li N, Fang F, Boyer JL, Christian WV, and Hammond CL (2009) OST alpha-OST beta: a key membrane transporter of bile acids and conjugated steroids. Front Biosci 14:2829-2844

Boyer JL, Trauner M, Mennone A, Soroka CJ, Cai SY, Moustafa T, Zollner G, Lee JY, and Ballatori N (2006) Upregulation of a basolateral FXR-dependent bile acid efflux transporter OSTalpha-OSTbeta in cholestasis in humans and rodents. Am J Physiol Gastrointest Liver Physiol 290:G1124-G1130.

Chai J, He Y, Cai SY, Jiang Z, Wang H, Li Q, Chen L, Peng Z, He X, Wu X, et al. (2012) Elevated hepatic multidrug resistance-associated protein 3/ATP-binding cassette subfamily C 3 expression in human obstructive cholestasis is mediated through tumor necrosis factor alpha and c-Jun NH2-terminal kinase/stressactivated protein kinase-signaling pathway. Hepatology 55:1485-1494

Chandra P, Zhang P, and Brouwer KLR (2005) Short-term regulation of multidrug resistance-associated protein 3 in rat and human hepatocytes. Am J Physio Gastrointest Liver Physiol 288:G1252-G1258.
Chen W, Cai SY, Xu S, Denson LA, Soroka CJ, and Boyer JL (2007) Nuclear receptors RXRalpha:RARalpha are repressors for human MRP3 expression. Am J Physio Gastrointest Liver Physiol 292:G1221-G1227.

Dawson PA, Hubbert ML, and Rao A (2010) Getting the mOST from OST: role of organic solute transporter, OSTalpha-OSTbeta, in bile acid and steroid metabolism. Biochim Biophys Acta 1801:994-1004.

Dawson PA, Lan T, and Rao A (2009) Bile acid transporters. J Lipid Res 50: 2340-2357.

Denson LA, Sturm E, Echevarria W, Zimmerman TL, Makishima M, Mangelsdorf DJ, and Karpen SJ (2001) The orphan nuclear receptor, shp, mediates bile acidinduced inhibition of the rat bile acid transporter, ntcp. Gastroenterology 121: $140-147$

Edwards JE, LaCerte C, Peyret T, Gosselin NH, Marier JF, Hofmann AF, and Shapiro D (2016) Modeling and experimental studies of obeticholic acid exposure and the impact of cirrhosis stage. Clin Transl Sci 9:328-336.

Fiorucci S, Rizzo G, Donini A, Distrutti E, and Santucci L (2007) Targeting farnesoid $\mathrm{X}$ receptor for liver and metabolic disorders. Trends Mol Med 13:298-309.

Geier A, Wagner M, Dietrich CG, and Trauner M (2007) Principles of hepatic organic anion transporter regulation during cholestasis, inflammation and liver regeneration. Biochim Biophys Acta 1773.283-308.

Gu X and Manautou JE (2010) Regulation of hepatic ABCC transporters by xenobiotics and in disease states. Drug Metab Rev 42:482-538.

Guo C, Yang K, Brouwer KR, St Claire RL, 3rd, and Brouwer KLR (2016) Prediction of altered bile acid disposition due to inhibition of multiple transporters: an integrated approach using sandwich-cultured hepatocytes, mechanistic modeling, and simulation. J Pharmacol Exp Ther 358:324-333.

Inokuchi A, Hinoshita E, Iwamoto Y, Kohno K, Kuwano M, and Uchiumi T (2001) Enhanced expression of the human multidrug resistance protein 3 by bile salt in human enterocytes. A transcriptional control of a plausible bile acid transporter. $J$ Biol Chem 276:46822-46829.

Jackson JP, Freeman KM, Friley WW, St Claire RL, 3rd, Black C, and Brouwer KR (2016) Basolateral efflux transporters: a potentially important pathway for the prevention of cholestatic hepatotoxicity. Appl In Vitro Toxicol 2:207-216.

Jiang T, Wang XX, Scherzer P, Wilson P, Tallman J, Takahashi H, Li J, Iwahashi M, Sutherland E, Arend L, et al. (2007) Farnesoid X receptor modulates renal lipid metabolism, fibrosis, and diabetic nephropathy. Diabetes 56:2485-2493.

Jung D, Elferink MG, Stellaard F, and Groothuis GM (2007) Analysis of bile acidinduced regulation of FXR target genes in human liver slices. Liver Int 27:137-144.

Landrier JF, Eloranta JJ, Vavricka SR, and Kullak-Ublick GA (2006) The nuclear receptor for bile acids, FXR, transactivates human organic solute transporteralpha and -beta genes. Am J Physiol Gastrointest Liver Physiol 290:G476-G485.

LeCluyse E, Madan A, Hamilton G, Carroll K, DeHaan R, and Parkinson A (2000) Expression and regulation of cytochrome P450 enzymes in primary cultures of human hepatocytes. J Biochem Mol Toxicol 14:177-188.

Lee H, Zhang Y, Lee FY, Nelson SF, Gonzalez FJ, and Edwards PA (2006) FXR regulates organic solute transporters alpha and beta in the adrenal gland, kidney, and intestine. $J$ Lipid Res 47:201-214.

Lee JK, Marion TL, Abe K, Lim C, Pollock GM, and Brouwer KLR (2010) Hepatobiliary disposition of troglitazone and metabolites in rat and human sandwich-cultured hepatocytes: use of Monte Carlo simulations to assess the impact of changes in biliary excretion on troglitazone sulfate accumulation. J Pharmacol Exp Ther 332:26-34.

Lefebvre P, Cariou B, Lien F, Kuipers F, and Staels B (2009) Role of bile acids and bile acid receptors in metabolic regulation. Physiol Rev 89:147-191.

Liu J, Lu H, Lu YF, Lei X, Cui JY, Ellis E, Strom SC, and Klaassen CD (2014) Potency of individual bile acids to regulate bile acid synthesis and transport genes in primary human hepatocyte cultures. Toxicol Sci 141:538-546.

Liu X, LeCluyse EL, Brouwer KR, Lightfoot RM, Lee JI, and Brouwer KLR (1999) Use of $\mathrm{Ca}^{2+}$ modulation to evaluate biliary excretion in sandwich-cultured rat hepatocytes. J Pharmacol Exp Ther 289:1592-1599.

Markham A and Keam SJ (2016) Obeticholic acid: first global approval. Drugs 76: $1221-1226$.

Modica S, Gadaleta RM, and Moschetta A (2010) Deciphering the nuclear bile acid receptor FXR paradigm. Nucl Recept Signal 8:e005.

Ohtsuki S, Schaefer O, Kawakami H, Inoue T, Liehner S, Saito A, Ishiguro N, Kishimoto W, Ludwig-Schwellinger E, Ebner T, et al. (2012) Simultaneous absolute protein quantification of transporters, cytochromes P450, and UDP-glucuronosyltransferases as a novel approach for the characterization of individual human liver: comparison with mRNA levels and activities. Drug Metab Dispos 40:83-92.

Ørntoft NW, Munk OL, Frisch K, Ott P, Keiding S, and Sørensen M (2017) Hepatobiliary transport kinetics of the conjugated bile acid tracer ${ }^{11} \mathrm{C}-\mathrm{CSar}$ quantified in healthy humans and patients by positron emission tomography. J Hepatol 67:321-327.

Oshio C and Phillips MJ (1981) Contractility of bile canaliculi: implications for liver function. Science 212:1041-1042.

Pfeifer ND, Yang K, and Brouwer KLR (2013) Hepatic basolateral efflux contributes significantly to rosuvastatin disposition I: characterization of basolateral versus biliary clearance using a novel protocol in sandwich-cultured hepatocytes. $J$ Pharmacol Exp Ther 347:727-736.

Rius M, Hummel-Eisenbeiss J, Hofmann AF, and Keppler D (2006) Substrate specificity of human ABCC4 (MRP4)-mediated cotransport of bile acids and reduced glutathione. Am J Physiol Gastrointest Liver Physiol 290:G640-G649.

Schonhoff CM, Webster CR, and Anwer MS (2013) Taurolithocholate-induced MRP2 retrieval involves MARCKS phosphorylation by protein kinase C $\epsilon$ in HUH-NTCP cells. Hepatology 58:284-292.

Seward DJ, Koh AS, Boyer JL, and Ballatori N (2003) Functional complementation between a novel mammalian polygenic transport complex and an evolutionarily ancient organic solute transporter, OSTalpha-OSTbeta. J Biol Chem 278:27473-27482.

Soisson SM, Parthasarathy G, Adams AD, Sahoo S, Sitlani A, Sparrow C, Cui J, and Becker JW (2008) Identification of a potent synthetic FXR agonist with an unexpected mode of binding and activation. Proc Natl Acad Sci USA 105 5337-5342. 
Soroka CJ, Ballatori N, and Boyer JL (2010) Organic solute transporter, OSTalphaOSTbeta: its role in bile acid transport and cholestasis. Semin Liver Dis 30: 178-185.

Staels B and Kuipers F (2007) Bile acid sequestrants and the treatment of type 2 diabetes mellitus. Drugs 67:1383-1392.

Sultan M, Rao A, Elpeleg O, Vaz FM, Abu Libdeh BY, Karpen SJ, and Dawson PA (2017) Organic solute transporter-beta (SLC51B) deficiency in two brothers with congenital diarrhea and features of cholestasis. Hepatology DOI: 10.1002/ hep.29516 [published ahead of print].

Swift B, Pfeifer ND, and Brouwer KLR (2010) Sandwich-cultured hepatocytes: an in vitro model to evaluate hepatobiliary transporter-based drug interactions and hepatotoxicity. Drug Metab Rev 42:446-471.

Teng S, Jekerle V, and Piquette-Miller M (2003) Induction of ABCC3 (MRP3) by pregnane X receptor activators. Drug Metab Dispos 31:1296-1299.

Thomas C, Pellicciari R, Pruzanski M, Auwerx J, and Schoonjans K (2008) Targeting bile-acid signalling for metabolic diseases. Nat Rev Drug Discov 7:678-693.

Thompson CG, Fallon JK, Mathews M, Charlins P, Remling-Mulder L, Kovarova M, Adamson L, Srinivas N, Schauer A, Sykes C, et al. (2017) Multimodal analysis of drug transporter expression in gastrointestinal tissue. AIDS 31:1669-1678.

Trivedi PJ, Hirschfield GM, and Gershwin ME (2016) Obeticholic acid for the treatment of primary biliary cirrhosis. Expert Rev Clin Pharmacol 9:13-26.

Wagner M, Zollner G, and Trauner M (2011) Nuclear receptors in liver disease. Hepatology 53:1023-1034.

Wang L, Soroka CJ, and Boyer JL (2002) The role of bile salt export pump mutations in progressive familial intrahepatic cholestasis type II. J Clin Invest 110:965-972.

Watanabe S, Smith CR, and Phillips MJ (1985) Coordination of the contractile activity of bile canaliculi. Evidence from calcium microinjection of triplet hepatocytes. Lab Invest 53:275-279.

Wolf KK, Brouwer KR, Pollack GM, and Brouwer KLR (2008) Effect of albumin on the biliary clearance of compounds in sandwich-cultured rat hepatocytes. Drug Metab Dispos 36:2086-2092.
Yang K, Guo C, Woodhead JL, St Claire RL, 3rd, Watkins PB, Siler SQ, Howell BA, and Brouwer KLR (2016) Sandwich-cultured hepatocytes as a tool to study drug disposition and drug-induced liver injury. J Pharm Sci 105:443-459.

Yang K, Pfeifer ND, Köck K, and Brouwer KLR (2015) Species differences in hepatobiliary disposition of taurocholic acid in human and rat sandwich-cultured hepatocytes: implications for drug-induced liver injury. J Pharmacol Exp Ther 353: 415-423.

Yu J, Lo JL, Huang L, Zhao A, Metzger E, Adams A, Meinke PT, Wright SD, and Cui $J$ (2002) Lithocholic acid decreases expression of bile salt export pump through farnesoid X receptor antagonist activity. J Biol Chem 277:31441-31447.

Zhang DW, Gu HM, Vasa M, Muredda M, Cole SP, and Deeley RG (2003) Characterization of the role of polar amino acid residues within predicted transmembrane helix 17 in determining the substrate specificity of multidrug resistance protein 3. Biochemistry 42:9989-10000.

Zhang P, Tian X, Chandra P, and Brouwer KLR (2005) Role of glycosylation in trafficking of Mrp2 in sandwich-cultured rat hepatocytes. Mol Pharmacol 67: 1334-1341

Zhang Y, Jackson JP, St Claire RL, 3rd, Freeman K, Brouwer KR, and Edwards JE (2017) Obeticholic acid, a selective farnesoid $\mathrm{X}$ receptor agonist, regulates bile acid homeostasis in sandwich-cultured human hepatocytes. Pharmacol Res Perspect 5: $1-11$.

Zollner G, Fickert P, Silbert D, Fuchsbichler A, Marschall HU, Zatloukal K, Denk H, and Trauner M (2003) Adaptive changes in hepatobiliary transporter expression in primary biliary cirrhosis. J Hepatol 38:717-727.

Address correspondence to: Kim L. R. Brouwer, Division of Pharmacotherapy and Experimental Therapeutics, UNC Eshelman School of Pharmacy, University of North Carolina at Chapel Hill, CB 7569, Chapel Hill, NC 275997569. E-mail: kbrouwer@unc.edu 